\title{
Effect of some treatments on quality and milling properties of barley
}

\author{
Ali, R. Gomaa \\ Crops Technology Department, Food Technology Research Institute, Agricultural Research Center, Giza, Egypt.
}

\begin{abstract}
The present work was conducted to study the effect of different treatments in barley grain before milling (drain in water for 8,16,24 and 32 hours ,hot air in oven for $1 / 2,1,11 / 2$ and 2hours, drain in hot water for $1 / 2$ $, 1,11 / 2$ and 2 hours, and drain in boiling $\mathrm{Ca}(\mathrm{OH}) 2$ solution( $1 \%$ ) for $1 / 2$ and one hours) . Results showed that, drain barley grains with water for 24 or 32 hours increased the extraction rate comparing with different treatments in addition to control (without any treatments) which were ( 87.60 and $88.50 \%$ ) respectively. Also, for chemical composition of barley flour with different treatments, showed that barley grains drain in water for 24 or 32 hours contained higher protein, fat ,crude fiber, ash and $\beta$-glucan comparing with all treatments in addition to control (without any treatments) which were (12 .59 and12.72,3.0 and 3.3, 4.69 and $4.74,2.46$ and $2.49,4.73$ and $4.78 \mathrm{~g} / 100 \mathrm{~g}$ on dry Wt)respectively. Also, contained the highest amount of minerals ( $\mathrm{Zn}, \mathrm{Ca}, \mathrm{Fe}$, $\mathrm{Mg}, \mathrm{Mn}, \mathrm{Na}$ and $\mathrm{k}$ ). From the results obtained, it could concluded that, drain barley grains with water for 24 or 32 hours showed better extraction rat, chemical composition and mineral content.
\end{abstract}

Keywords: Barley grain, extraction rate, chemical composition, minerals, colour.

\section{Introduction}

Today' health-conscious consumers are looking for foods that will fit their health lifestyle. Cereals constitute the most important food component because they have high carbohydrate content, cereals such as wheat, corn and barley also provide vitamins, trace minerals, dietary fiber and bioactive compounds [Madhujith and Shahidi (2007)]. Barley (Hordeum vulgare L.) is a widely consumed cereal. Barley was one of the first agricultural domesticates together with wheat, pea, lentils dating from about 10,000 years ago [Smith, 1998].Unfortunately, barley has not been perceived as such an important grain in human diet. Barley is more associated with the beer industry, malting, and animal feed; $80-90 \%$ of barley production is used for malting and animal feed stocks [ Baik and Ullrich (2008)] .

Barley (Hordeum vulgare) is an ancient and important cereal grain and occupies about $9.4 \%$ of the total world area under cereal production and ranks fifth in the world [FAO, 2007.]. It is a functional grain and an excellent source of b-glucan, B-complex vitamins, tocotrienols and tocopherols. In India barley is the most important cereal crop in winter after wheat occupying an area of nearly 0.7 million hectares with total production of 1.4 million tones. At present only $2 \%$ of the barley is used as human food [ Baik and Ullrich (2008)] .The reasons that make barley unpopular as human food are: (i) presence of a husk that is difficult to remove, (ii) most of the barley is used up by the malting and brewing industry, (iii) barley lacks the gluten proteins therefore cannot be used in leavened bakery products and (iv) strong taste and gummy mouth feel of whole barley kernels. Barley should be used as a human food because it has one of the highest levels (up to $6 \%$ ) of $\beta$-glucan, a water-soluble polysaccharide, nutritionally classified as soluble dietary fiber [Dandey and Bobraszczyk (2001)]. $\beta$ Glucan has become commercially important because of its effectiveness in reducing postprandial serum glucose levels, insulin response and serum cholesterol concentrations \{Cavallero et al, (2002); [Behall, et al (2004)\}.

Barley is gaining renewed interest as an ingredient for production of functional foods due to its high contents of bioactive compounds such as bglucans, tocopherols and tocotrienols. Moreover, there are many classes of phenolic compounds in barley, such as benzoic and cinnamic acid derivatives, proanthocyanidins, quinones, flavonols, chalcones, flavones, flavanones and amino phenolic compounds. [Holtekjølen, et al. (2008)].

Among the cereal grains barley has higher antioxidant activity as compared to the more widely consumed cereals wheat and rice. The risk imposed by the consumption of free radicals and oxidation products towards various forms of cancer and cardiovascular disease could be lowered by the intake of dietary phenolics. Barley contains many phenolic compounds in the free and bound form; these compounds include benzoic and cinnamic acid derivatives, proanthocyanidins, quinines, flavonols, chalcones, flavones, flavanones, and amino phenolic compounds \{[ Goupy, et al, (1999)] ; [Shahidi ( 2009).] \}.

Barley (Hordeum vulgare L.) is one of the major cereal grains in Canada with 8.21 million tons of production in 2012 [MacLeod, et al (2012)]. Hulless barley differs from hulled barley in that hullcoating is removed during mechanical processing of the grain [Thomason, et al (2009)]. Recently, four hulless barley cultivars with altered carbohydrate 
composition were developed at the Crop Development Centre (CDC), University of Saskatchewan, distinguished by their amylose (1e40\% DM) and b-glucan (5e10\% DM) content, including zero-amylose waxy, CDC Fiber; 5\%amylose waxy, CDC Rattan; normal-amylose, CDC McGwire and high-amylose, HB08302. In feed analysis, it is possible that the metabolic characteristics of feed nutrients can be determined by their related molecular structures and biopolymer conformation. However, conventional reagent-based analysis methods are not able to identify the biopolymer conformations of feeds on a molecular basis due to the damage caused by these harsh chemicals to feed samples and their related internal structure\{ [Budevska, 2002.] ; [Liu, 2011] \}.

Barley is rarely used in the food industry, even though it is a main source of b-glucans, which have important health benefits and a technological role in food. This work evaluated the humid extraction of barley b-glucans and partially characterized them [Valeria, et al (2014) ]. Also, barley flour, prepared from pearled grain through hammer milling or roller milling, can easily be incorporated into wheat based products, including bread, cakes, cookies, noodles and extruded snack foods. [Newman and Newman, 1991]. Wheat bread with barley flour added at 15$20 \%$ was acceptable in overall flavor, appearance and texture, but an increased proportion of barley flour caused a decrease in loaf volume, dull brown colour and hard crumb texture [Dhingra and Jood, (2004)].

On December 23, 2005, the Food and Drug Administration (FDA). announced that whole grain barley and barley containing products are allowed to claim that they reduce the risk of coronary heart disease (CHD). Consequently, consumers can except to see whole barley and dry milled barley products such as flakes, grits, flour, meal and barley meal bearing the health benefit claim. Coronary heart Disease (CHD) is the cause of almost 5000,000 deaths annually. Scientific evidence shows that adding barley to one's diet can provide health benefits of serum cholesterol lowering.

The objectives of this study effect of some treatments in barley grain before milling ( drain in water for $8,16,24$ and 32 hours ,hot air in oven for $1 / 2,1,11 / 2$ and 2 hours, drain in hot water for $1 / 2,1,11 / 2$ and 2 hours, and drain in boiling $\mathrm{Ca}(\mathrm{OH}) 2$ solution( $1 \%$ ) for $1 / 2$ and one hours) on quality and milling properties of barley grain.

\section{Materials and methods \\ 2.1. Materials}

Barley grains (Hordeum Vulgare L., Giza131) were obtained from Barley Research Department, Field Research Institute, Agriculture Research Center, Giza, Egypt.

2.2. Preparation of grains for milling
Barley grains were treated with the following treatments before milling :-

1 -Without any treatments. (Control)

2- Drain in water for $(8,16,24$ and 32 hours).

3 - Hot air in oven for $(1 / 2,1,11 / 2$ and 2 hours $)$ at $100 \mathrm{C}^{\circ}$..

4- Drain in hot water for $(1 / 2,1,11 / 2$ and 2 hours $)$ at $100 \mathrm{C}^{\circ}$.

5- Drain in $\mathrm{Ca}(\mathrm{OH}) 2$ solution (1/2 and 1 hours) at $100 \mathrm{C}^{\circ}$.

Then, barley grains were milled using Qudrumat Senior Laboratory Mill according to A. A. C. C. (2002).

2.3. Determination of particle size of different barley treatment.

Barley flour ( with different treatments ) were sieved by vertical Sieving Shaker (Model D5657HAAN, Germany) with holes sizes 500, 420, 250,210 , and $150 \mu \mathrm{m}$ to determine particles size of different treatments of barley grain.

\subsection{Chemical analysis:}

Moisture, crude protein, crude fiber, total lipids and ash contents were determined in barley flour and bran, according to the methods of A.O.A.C. (2005). Total carbohydrates were calculated by difference according to the following equation:- Total carbohydrates $=100-(\%$ crude protein $+\%$ crude fat $+\%$ ash + total dietary fiber). Dietary fibers content determined according to the A.O.A.C. (2005) - $\beta$-glucan content determined according to the method of Izydorczyk et al.,(1998). Potassium and sodium contents were estimated using flame photometer as given by A.O.A.C. (1995). Calcium, iron and zinc contents were measured using the atomic absorption spectrophotometer Perken Elmer model 20180 following the method of A.O.A.C. (1995). Determination of minerals: Iron, zinc, calcium, magnesium, sodium and potassium were determined using atomic absorption spectrophotometer (Perkin Elmer Instrument Model 2380) according to the methods recommended by the A.O.A.C. (2005).

\subsection{Colour characteristics:-}

The colour of barley flour from different treatments before barley grain milling are measured instrumentally using a hand-held Chromameter (model CR-400, Konica Minolta, Japan ). The results were expressed in terms of: $\mathrm{L}^{*}$ (lightness), $\mathrm{a}^{*}$ (redness-greenness) and $\mathrm{b}^{*}$ (yellowness-blueness).

\section{Results and Discussion}

-Milling properties of different Barley treatments.

Barley flour and bran from different treatments before milling grain ( drain in water for 8,16,24 and 32 hours ,hot air in oven for $1 / 2,1,11 / 2$ and 2hours , drain in hot water for $8,16,24$ and 32 hours, drain in boiling $\mathrm{Ca}(\mathrm{OH}) 2$ solution for $1 / 2$ and one hours) are 
shown in Table (1).Results in Table (1) showed that ,drain barley grains with water for 24 or 32 hours, cause highly extraction rate comparing with all treatments in addition to control (without any treatments) which were ( 87.60 and $88.50 \%)$ respectively. On another hand, barley grains which treated with hot water for $1 / 2$ hour had the lowest extraction rat $(59.74 \%)$. Also the same trend was noticed in bran extraction. This effect may be as a result of drain barley grains with water without any heat treatment, in which increased solubility and extraction rat. On another hand, heat treatment could cause decreased in solubility and extraction rat as a result of gelatinization of starch or change in protein profile.

-Chemical composition of barley flour as affected with different with different treatments.

Chemical composition of flour from different treatments before milling barley grain are shown in Table (2). Data showed that protein, fat ,crude fiber, ash and b-glucan content of drain barley grains with water for 24 or 32 hours, were higher comparing with all treatments in addition to control (without any treatments) which were ( 12.59 and12.72,3.0 and $3.3,4.69$ and4.74, 2.46 and $2.49,4.73$ and4.78 $\mathrm{g} / 100 \mathrm{~g}$ on dry $\mathrm{Wt}$ ) respectively comparing with all treatments in addition to control (without any treatments), This may be as a result of its high extraction rat comparing with all treatments. Data showed also, barley grains which treated with hot water for $1 / 2$ hour had the lowest protein, fat ,crude fiber, ash and $\beta$-glucan content ( 8.59 ,2.05,3.20,1.68 and $3.22 \mathrm{~g} / 100 \mathrm{~g}$ on dry $\mathrm{Wt}$ ) excepted for carbohydrate content, it contained the highest amount $(84.48 \mathrm{~g} / 100 \mathrm{~g}$ on dry Wt).

These results are in agreement with Person, (1976). And Pedersen, (1994). Who reported that In the milling process, the grains may be fractionated into different types of flour and, also, with decreasing extraction rates in milling, more and more of the outer grain layers are removed resulting in the loss of dietary fiber and associated bioactive compounds such as vitamins B group, tryptophan and lignin. The refining of flour greatly affects the protein content as it decreases from $14.2 \%$ at $100 \%$ extraction to $12.7 \%$ at $66 \%$ extraction of flour. It is the response to the removal of germ and aleurone layer as bran; both are relatively rich in protein Pedersen, (1994). It has been observed that by increasing the extraction rate, the amount of protein, fat, fiber, ash, wet gluten, water absorption and color of wheat flour increase.

Form the results in Table(2), for minerals content, the same trend was noticed, drain barley grains with water for 24 or 32 hours, contained highest amount of ( $\mathrm{Zn}, \mathrm{Ca}, \mathrm{Fe}, \mathrm{Mg}, \mathrm{Mn}, \mathrm{Na}$ and $\mathrm{k}$ ) comparing with all treatments in addition to control (without any treatments). This increase might be due to the higher proportion of pericarp and aleuronic layer. These results agree with Nilsson, et al (1997). Who mentioned that ash contents increased with increasing the extraction rate.

-Particles size of different treatments on barley flour.

Particles size of barley flour from different treatments before milling barley grain and control (without any treatments) are shown in Table (3).Data in Table(3) showed that, the content of large particles size almost in( 250,420 and 500)of barley treated with hot air in oven, hot water and drain in $\mathrm{Ca}(\mathrm{OH}) 2$ solution. Mean while small particles size almost in (210 and150) of barley treated with water and control (without any treatments).

-Colour characteristics of different treatments on barley flour.

Colour characteristics of different treatments on barley flour are shown in Table (3).Data in Table (4) show that, flour lightness $\left(\mathrm{L}^{*}\right)$ were higher in barley flour for control sample and barley flour which its grain treated with water, Main while barley flour from grain treated with $\mathrm{Ca}(\mathrm{OH}) 2$ solution was the lowest lightness $\left(\mathrm{L}^{*}\right)$.This may be due to the effect of $\mathrm{Ca}(\mathrm{OH}) 2$ solution. Also, For the level $\left( \pm \mathrm{a}^{*}\right)$ redness-greenness and $\left( \pm b^{*}\right)$ yellowness-blueness, results show that there are slightly change in rednessgreenness $\left( \pm \mathrm{a}^{*}\right)$ in all treatments of barley grain flour.

From above results, it could be concluded that, drain barley grains with water for 24 or 32 hours showed better extraction rat, chemical composition and mineral content. 
Table 1. Milling properties as affected with different barley grain treatments

\begin{tabular}{|c|c|c|c|c|c|c|c|c|c|c|c|c|c|c|c|}
\hline \multirow{2}{*}{$\begin{array}{l}\text { Treatments } \\
\text { Products }\end{array}$} & \multirow[t]{2}{*}{ Control } & \multicolumn{4}{|c|}{$\begin{array}{l}\text { With drain in cold water } \\
\text { (hours ) }\end{array}$} & \multicolumn{4}{|c|}{$\begin{array}{l}\text { With hot air in oven } \\
\text { (hours ) }\end{array}$} & \multicolumn{4}{|c|}{$\begin{array}{l}\text { With drain in hot water } \\
\text { (hours ) }\end{array}$} & \multicolumn{2}{|c|}{$\begin{array}{c}\text { With drain in } \\
\mathrm{Ca}(\mathrm{OH}) 2 \\
\text { solution(hours) }\end{array}$} \\
\hline & & 8 & 16 & 24 & 32 & $1 / 2$ & 1 & $11 / 2$ & 2 & $1 / 2$ & 1 & $11 / 2$ & 2 & $1 / 2$ & 1 \\
\hline Flour & 78.10 & 78.90 & 80.20 & 87.60 & 88.50 & 82.22 & 71.20 & 63.58 & 62.74 & 59.74 & 69.66 & 65.26 & 61.28 & 84.25 & 80.65 \\
\hline Bran & 21.90 & 21.10 & 19.80 & 12.40 & 11.50 & 17.78 & 28.80 & 36.42 & 37.26 & 40.26 & 30.34 & 34.74 & 38.72 & 15.75 & 19.35 \\
\hline
\end{tabular}


Table 2. Chemical composition and minerals content of barley flour as affected with different treatments.

\begin{tabular}{|c|c|c|c|c|c|c|c|c|c|c|c|c|c|c|c|}
\hline \multirow[t]{2}{*}{$\begin{array}{c}\text { Treatments } \\
\text { Components }(\%)\end{array}$} & \multirow[t]{2}{*}{ Control } & \multicolumn{4}{|c|}{$\begin{array}{l}\text { With drain in cold water } \\
\text { (hours ) }\end{array}$} & \multicolumn{4}{|c|}{$\begin{array}{c}\text { With hot air in oven } \\
\text { (hours ) }\end{array}$} & \multicolumn{4}{|c|}{$\begin{array}{c}\text { With drain in hot water } \\
\text { (hours ) }\end{array}$} & \multicolumn{2}{|c|}{$\begin{array}{c}\text { With drain in } \\
\mathrm{Ca}(\mathrm{OH}) 2 \\
\text { solution(hours }\end{array}$} \\
\hline & & 8 & 16 & 24 & 32 & $1 / 2$ & 1 & $11 / 2$ & 2 & $1 / 2$ & 1 & $11 / 2$ & 2 & $1 / 2$ & 1 \\
\hline Protein & 11.23 & 11.34 & 11.53 & 12.59 & 12.72 & 11.82 & 10.23 & 9.14 & 9.02 & 8.59 & 10.01 & 9.38 & 8.81 & 12.11 & 11.59 \\
\hline Fat & 2.68 & 2.70 & 2.75 & 3.00 & 3.03 & 2.82 & 2.44 & 2.18 & 2.15 & 2.05 & 2.39 & 2.23 & 2.10 & 2.89 & 2.76 \\
\hline Crude fiber & 4.19 & 4.23 & 4.30 & 4.69 & 4.74 & 4.41 & 3.81 & 3.41 & 3.36 & 3.20 & 3.65 & 3.50 & 3.28 & 4.51 & 4.32 \\
\hline Ash & 2.20 & 2.22 & 2.25 & 2.46 & 2.49 & 2.31 & 2.00 & 1.79 & 1.76 & 1.68 & 1.96 & 1.83 & 1.72 & 2.37 & 2.27 \\
\hline Carbohydrates & 79.97 & 79.51 & 79.17 & 77.26 & 77.02 & 78.64 & 81.52 & 83.48 & 83.71 & 84.48 & 81.99 & 83.06 & 84.09 & 78.12 & 79.06 \\
\hline$\beta$ - glucan & 4.22 & 4.26 & 4.33 & 4.73 & 4.78 & 4.44 & 3.85 & 3.43 & 3.39 & 3.22 & 3.76 & 3.52 & 3.31 & 4.55 & 4.35 \\
\hline \multicolumn{16}{|c|}{ Minerals content (mg/ 100g) } \\
\hline $\mathbf{Z n}$ & 2.02 & 2.04 & 2.07 & 2.26 & 2.28 & 2.12 & 1.84 & 1.64 & 1.62 & 1.54 & 1.80 & 1.68 & 1.58 & 2.17 & 2.08 \\
\hline $\mathbf{C a}$ & 31.44 & 31.67 & 32.26 & 35.19 & 35.54 & 33.08 & 28.62 & 25.57 & 25.22 & 24.04 & 28.03 & 26.16 & 24.63 & 33.90 & 32.37 \\
\hline $\mathbf{F e}$ & 1.95 & 1.96 & 1.97 & 1.99 & 1.98 & 1.97 & 1.67 & 1.63 & 1.61 & 1.52 & 1.66 & 1.68 & 1.51 & 2.00 & 1.99 \\
\hline Mg & 33.03 & 33.19 & 33.48 & 34.15 & 35.10 & 33.95 & 31.29 & 29.95 & 28.66 & 27.45 & 29.00 & 28.90 & 26.61 & 34.70 & 33.90 \\
\hline Mn & 0.149 & 0.168 & 0.179 & 0.188 & 0.193 & 0.173 & 0.161 & 0.152 & 0.149 & 0.133 & 0.160 & 0.150 & 0.136 & 0.171 & 0.169 \\
\hline $\mathbf{N a}$ & 70.18 & 71.00 & 71.51 & 72.30 & 74.53 & 70.33 & 67.85 & 65.44 & 65.18 & 63.18 & 66.33 & 64.22 & 60.15 & 73.85 & 71.32 \\
\hline $\mathbf{K}$ & 217.3 & 219.2 & 221.1 & 222.4 & 225.1 & 218.4 & 209.1 & 206.1 & 202.0 & 199.0 & 208.1 & 205.7 & 188.2 & 224.2 & 219.4 \\
\hline
\end{tabular}


Table3. Particles size of barley flour as affected with different treatments.

\begin{tabular}{|c|c|c|c|c|c|c|c|c|c|c|c|c|c|c|c|}
\hline \multirow{2}{*}{$\begin{array}{c}\text { Treatments } \\
\text { Particle size of } \\
\text { barley flour }(\mu \mathrm{m})\end{array}$} & \multirow[t]{2}{*}{ Control } & \multicolumn{4}{|c|}{$\begin{array}{c}\text { With drain in cold water } \\
\text { (hours ) }\end{array}$} & \multicolumn{4}{|c|}{$\begin{array}{c}\text { With hot air in oven } \\
\text { (hours ) }\end{array}$} & \multicolumn{4}{|c|}{$\begin{array}{c}\text { With drain in hot water } \\
\text { (hours ) }\end{array}$} & \multicolumn{2}{|c|}{$\begin{array}{c}\text { With drain in } \\
\mathrm{Ca}(\mathrm{OH}) 2 \\
\text { solution(hours) }\end{array}$} \\
\hline & & 8 & 16 & 24 & 32 & $1 / 2$ & 1 & $11 / 2$ & 2 & $1 / 2$ & 1 & $11 / 2$ & 2 & $1 / 2$ & 1 \\
\hline$\geq \mathbf{5 0 0}$ & 3.2 & 3.1 & 3.2 & 2.9 & 3.0 & 43.6 & 38.8 & 50.0 & 44.4 & 42.8 & 38.4 & 43.2 & 33.2 & 25.6 & 28.9 \\
\hline$>420$ & 1.4 & 1.3 & 1.2 & 1.1 & 1.0 & 22.4 & 23.6 & 18.4 & 17.2 & 22.4 & 27.2 & 28.4 & 27.6 & 25.2 & 27.3 \\
\hline$>250$ & 7.5 & 7.3 & 7.5 & 7.2 & 7.1 & 22.0 & 18.8 & 16.4 & 25.6 & 30.8 & 18.0 & 26.0 & 14.0 & 26.8 & 21.7 \\
\hline$>210$ & 39.8 & 40.1 & 39.9 & 39.6 & 39.2 & 0.8 & 11.2 & 1.2 & 0.4 & 0.5 & 2.4 & 0.4 & 0.4 & 15.6 & 11.9 \\
\hline$>150$ & 38.5 & 38.4 & 38.6 & 37.9 & 38.0 & 7.2 & 5.6 & 7.2 & 5.6 & 1.3 & 6.4 & 0.8 & 16.8 & 3.2 & 7.6 \\
\hline$\leq 150$ & 9.6 & 9.8 & 9.6 & 11.3 & 11.7 & 4.0 & 2.0 & 6.8 & 6.8 & 2.2 & 7.6 & 1.6 & 8.0 & 3.6 & 2.6 \\
\hline Total & 100 & 100 & 100 & 100 & 100 & 100 & 100 & 100 & 100 & 100 & 100 & 100 & 100 & 100 & 100 \\
\hline
\end{tabular}

Table 4. Colour characteristics of barley flour as affected with different treatments.

\begin{tabular}{|c|c|c|c|c|c|c|c|c|c|c|c|c|c|c|c|}
\hline \multirow[t]{2}{*}{ Treatments } & \multirow[t]{2}{*}{ Control } & \multicolumn{4}{|c|}{$\begin{array}{l}\text { With drain in cold water } \\
\text { (hours ) }\end{array}$} & \multicolumn{4}{|c|}{$\begin{array}{l}\text { With hot air in oven } \\
\text { (hours ) }\end{array}$} & \multicolumn{4}{|c|}{$\begin{array}{l}\text { With drain in hot water } \\
\text { (hours ) }\end{array}$} & \multicolumn{2}{|c|}{$\begin{array}{c}\text { With drain in } \\
\mathrm{Ca}(\mathrm{OH}) 2 \\
\text { solution(hours) }\end{array}$} \\
\hline & & 8 & 16 & 24 & 32 & $1 / 2$ & 1 & $11 / 2$ & 2 & $1 / 2$ & 1 & $11 / 2$ & 2 & $1 / 2$ & 1 \\
\hline $\mathbf{L}^{*}$ & 61.16 & 60.21 & 59.19 & 58.58 & 58.11 & 58.14 & 57.46 & 57.92 & 56.21 & 59.41 & 58.98 & 58.12 & 57.73 & 48.93 & 46.44 \\
\hline $\mathbf{a}^{*}$ & 6.67 & 6.61 & 6.6. & 6.55 & 6.55 & 6.52 & 6.51 & 6.52 & 6.48 & 6.50 & 6.49 & 6.49 & 6.49 & 6.39 & 6.30 \\
\hline b* & 24.29 & 24.21 & 24.22 & 24.18 & 24.11 & 24.17 & 24.18 & 24.22 & 24.18 & 24.23 & 24.21 & 24.19 & 24.14 & 24.08 & 24.01 \\
\hline
\end{tabular}
WHERE:-

(L*):- Lightness.

+a: red, -a: green $\left.\quad a^{*}\right):-($

b*) :- b: yellow, -b: blue.( 


\section{References}

A. A. C. C. (2002). Approved methods of the American Association of Cereal Chemists. Published by the American Association of Cereal Chemists Inc. St. Paul., Minnesota, USA.

A.O.A.C. (1995). Official methods of analysis of the association of official analytical chemists 15th Washington D.C. USA.

A.O.A.C. (2005).Official methods of AOAC. 18 edition, 2005 current through revision 1, 2006 Basic sensory methods for food Evaluation .IDRC, Ottawa Ontario, Canada.

Baik, B.K., and Ullrich, S.E., 2008. Barley for food: characteristics, improvement, and renewed interest. Critical review. Journal of Cereal Science 30, 1-10.

Behall, K.M., Scholfield, D.J., and Hallfrisch, J., 2004. Diets containing barley significantly reduce lipid in mildly hypercholesterolemic men and women. American Journal of Clinical Nutrition 80, 1185-1193.

Budevska, B.O., 2002. Applications of vibrational spectroscopy in life, pharmaceutical and natural sciences. In: Chalmers, J.M., Griffiths, P.R. (Eds.), Handbook of Vibrational Spectroscopy, vol. 5. John Wiley and Sons Inc., NY,

Cavallero, A., Empilli, S., Brighenti, F., and Stanco, A.M., 2002. High (1/3, 1/4)-b glucan barley fractions in bread making and their effects on human glucemic response. Journal of Cereal Science 36, 59-66.

Dandey, D., and Bobraszczyk, B.J., 2001. Cereals and Cereal Products Chemistry and Technology. Aspen Publication, Maryland.

Dhingra, S., and Jood, S., 2004. Effect of flour blending on functional, baking and organoleptic characteristics of bread. International Journal of Food Science \&Technology 39, 213-222.

FAO, 2007. <http://www.fao.org>.

Food and Drug Administration (2005). FDA allows barley products to claim reduction in risk of coronary heart disease. FDA News, December 23, 2005. Accessed November, 2006.

Goupy,P. , Hugues, M., Boivin , P. and Amiot , M.J. (1999).Antioxidant composition and activity of barley (Hordeum vulgare) and malt extracts and of isolated phenolic compounds Journal of the Science of Food and Agriculture, 79 : 1625-1634.

Holtekjølen A.K.; Bævre A. B.; Rødbotten M. ; Berg H. and KnutsenS.H.(2008). Antioxidant properties and sensory profiles of breads containing barley flour. Food Chemistry, 110 ( 2) : 414-421.

Izydorczyk, M.S. , Macri, L. J. and Macgregor A.W. (1998).Structure and physicochemical properties of barley non- starch polysaccharides 1.water extracted b- glucans and arabinoxylanes. Carbohydrate polymers, 35:249 -259.

Liu, N., and Yu, P., 2011. Molecular clustering, interrelationships and carbohydrate conformation in Hull and seeds among barley cultivars. J. Cereal Sci. 53, 379-383.

MacLeod, A.L., Edney, M.J., and Izydorczyk, M.S., 2012. Quality of Western Canadian Malting Barley. Canadian Grain Commission, pp. 1e20, 1182-4417.

Madhujith, T., and Shahidi, F. (2007). Antioxidative and antiproliferative properties of selected barley (Hordeum vulgare L.) cultivars and their potential for inhibition of low density lipoprotein (LDL) cholesterol oxidation. Journal of Agriculture and Food Chemistry, 55, 5018-5024.

Newman, R.K., and Newman, C.W., 1991. Barley as a food grain. Cereal Foods World 36, 800-805.

Nilsson, M., Aman, P. and Harkonen, H. (1997). Content of nutrients and lignans in roller milled fractions of rye. J. Sci. Food Agric. 73: 143-148.

Pedersen, J. (1994). Insects: identification, damage and detection. In: Sauer DB (ed.) Storage of Cereal Grains. Am. Assoc. Cereal Chem. St. Paul Minnesota, USA. pp. 435-489.

Person D. (1976). The chemical analysis of food 7th Ed. Churchill, London, UK.

pp. 3720-3732.

Shahidi , F.( 2009). Nutraceuticals and functional foods: Whole versus processed foods Review. Trends in Food Science \& Technology, 20 :376-387.

Smith, B.D., 1998. The Emergence of Agriculture. Scientific American Library, HPHLP, New York, $231 \mathrm{pp}$.

Thomason, W.E., Brooks, W.S., Griffey, C.A., and Vaughn, M.E.( 2009). Hulless barley seeding rate effects on grain yield and yield components. Crop Sci. 49, 342-346.

Valeria M., Limberger-Bayer A., Alicia de Francisco B., Aline Chan B., Tatiana Oro B., Paulo J. Ogliari c., Pedro L.M. and Barreto B. (2014). Barley b-glucans extraction and partial characterization. Food Chemistry, 154: 84-89. 


\section{تأثير بعض المعاملات على خصائص جودة و طدن الثعير \\ رفاعي جمعة علي \\ قسم بحوث تكنولوجيا المحاصيل الحقلية ـ معهد بحوث تكنولوجيا الأغذية \\ مركز البحوث الزراعية - جيزة - مصر بحر}

يعتبر الثعير من المحاصيل الهامة لما له من خصائص غذائية قيمه نظرا لاحتوائه على العديد من المكونات منل البيتا جلوكان و التكوفيرولات

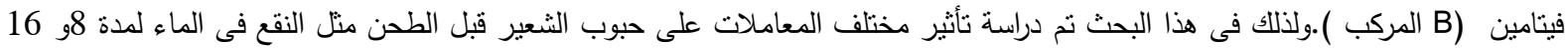

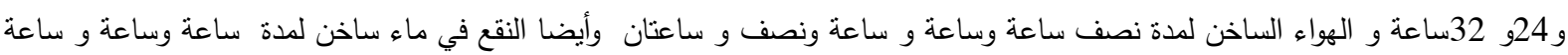
ونصف و ساعتان و كذالك المعاملة بمحلول هيدروكسيد الكالسيوم (1\%) لددة نصف ساعة وساعة 0

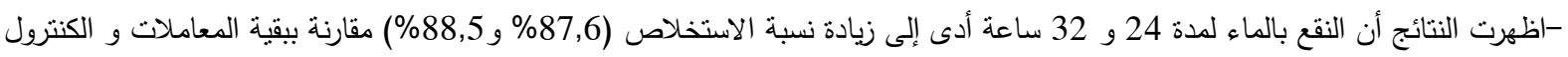

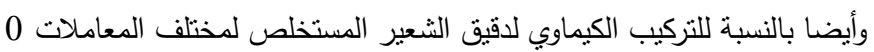
- كما أظهرت الننائج أن النقع بالماء لمدة 24 و 32 ساعة أدى إلى زيادة نسبة البروتين والدهون والألياف الخام و الرماد و بيتا جلوكان

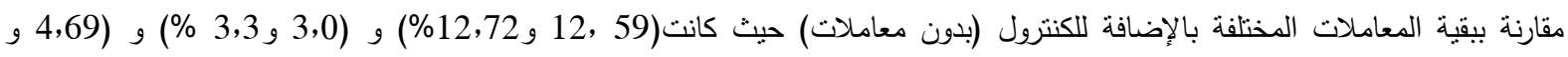
4,74\%) و (2,46 و 2,49 \%) و 4,73 و 4,78\%) على أساس الوزن الجاف 0 هذا بالإضافة إلى احتوائهما على نسبة أعلى من المعادن (الزنك و الكالسيوم و الحديد و المغنسيوم و المنجنيز و الصوديوم و البوتاسيوم).

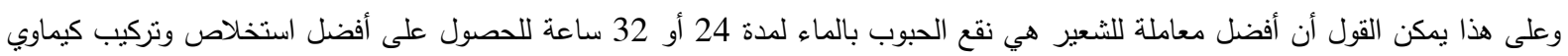
للاقيق الناتج. 